\title{
HISTOPATHOLOGY OF MIXED INFECTIONS IN REDCLAW CRAYFISH (Cherax quadricarinatus) TISSUES
}

\author{
Dewi Syahidah $^{\mathrm{a}, \mathrm{b}_{*}}$ and Leigh Owens ${ }^{\mathrm{b}}$ \\ ${ }^{a}$ Institute for Mariculture Research and Fisheries Extension (IMRAFE), Gondol Indonesia \\ bJames Cook University (JCU), Townsville, Australia \\ *Corresponding author: dewi.syahidah@my.jcu.edu
}

\begin{abstract}
Redclaw crayfish (C. quadricarinatus) diseases have become an important issue with a number of reports from farms in Australia since the 1990s. About 30 Adult crayfish were housed at SVBS JCU and were given mixed food as required for 3 wks. Crayfish samples were preserved at $\mathrm{D}_{21}$ by injecting the cephalothorax and abdominal muscles with Davidson's fixative (10mL of Davidson per $1 \mathrm{~g}$ crayfish). Histological examination was conducted by longitudinally slicing the cephalothorax, abdomen, and gill tissues at approximately $2-3 \mathrm{~mm}$ thickness to obtain separate histological sections of the tissues. Sections were cut at $5 \mu \mathrm{m}$ and stained with Mayer's hematoxylin and eosin (H\&E), Gram-Twort, Periodic Acid-Schiff (PAS), and phosphotungstic acid-eosin. An Olympus EC microscope was used to view the sections and the photographs were taken using QCapture.Pro. The results showed melanisation in the hepatopancreatic tissues, hemolymph and gills; Haemocytic aggregation in the hemolymph; Fungal hyphae in the gills; Multiple nodule formation surrounded by melanisation with continued haemocytic aggregation and whirling, early stage of catabolism and bacterial colonies were identified in the muscles. In conclusion, histopathological analyses in this study that redclaw crayfish is susceptible for mixed infection from bacteria, fungi, and virus.
\end{abstract}

Keywords : Bacteria, fungi, histopathology, infection, redclaw crayfish, virus

\begin{abstract}
Abstrak
Penyakit udang karang capit merah (C. quadricarinatus) telah menjadi masalah penting dengan sejumlah laporan dari budidayanya di Australia sejak 1990-an. Penelitian ini menggunakan 30 lobster dewasa ditempatkan di SVBS JCU and diberi makanan campuran selama 3 minggu. Sampel crayfish diawetkan pada H-21 dengan menyuntikkan cephalothorax and otot perut dengan fiksatif Davidson (10 ml Davidson per $\mathrm{g}$ crayfish). Analisa histologis dilakukan dengan mengiris cephalothorax, abdomen, and jaringan insang secara longitudinal dengan ketebalan sekitar 2-3mm untuk mendapatkan bagian histologis terpisah dari jaringan. Histologi section dipotong setebal $5 \mu \mathrm{m}$ and diwarnai dengan hematoxylin and eosin (H\&E) Mayer, Gram-Twort, Schiff Asam Periodik (PAS), and fosfotungstik acid eosin. Mikroskop Olympus EC digunakan untuk melihat jaringan and gambar diambil menggunakan QCapture.Pro. Hasil penelitian menunjukkan melanisasi pada jaringan hepatopancreatic, hemolymph and insang; Agregasi hemosit dalam hemolymph; Hifa jamur pada insang; Pembentukan multi nodul yang dikelilingi oleh melanisasi dengan agregasi hemositosis menyerupai putaran yang kontinyu, tahap awal katabolisme and koloni bakteri diidentifikasi pada otot. Kesimpulan dari analisis histopatologis dalam penelitian ini adalah udang karang rentan terhadap infeksi campuran dari bakteri, jamur, and virus.
\end{abstract}

Kata Kunci : Bakteri, histopatologis, infeksi, jamur, uandg karang capit merah, virus

\section{INTRODUCTION}

Redclaw crayfish (C. quadricarinatus) are native to the top of Cape York Peninsula and the river systems flowing into the Gulf of Carpentaria, Arafura Sea and Southern Papua New Guinea. It has become an economically important aquaculture species because of its marked preference for the slower moving reaches of the rivers, lakes, and lagoons. In

Article history:

Diterima / Received 07-12-2019

Disetujui / Accepted 10-06-2020

Diterbitkan /Published 31-07-2020 addition, it can tolerate a broad range of water quality and climatic conditions but is generally not considered to be quite as robust as the yaby family $(C$. destructor) [1].

Since the early 1980s there has been broad interest in redclaw crayfish aquaculture. Industry pioneers were quick to learn of the species' positive aquacultural attributes, such as fast growth rates, ease of reproduction, lack of any free-living larval stages, gregariousness, and the 
ability to tolerate poor water quality conditions. That interest stimulated research which led to the development of optimum husbandry and best practice techniques. Even so, the redclaw farming industry in Queensland has not lived up to early expectations and predictions, and production has remained relatively low. There are very few licensed redclaw growers in the Territory [1], [2].

Following the establishment of the industry, crayfish diseases have become an important issue with a number of infections being described from farms in Australia since the 1990s. The causative agents varied, ranging from bacteria, fungi to viruses.

Some bacteria, including Acinetobacter sp., Leucothrix mucor sp., Aeromonas sp., Flavobacterium sp., Citrobacter sp., Pseudomonas sp., Corynebacterium sp., Bacillus sp., Micrococcus sp., and Staphylococcus sp., Vibrio sp. are reported to cause bacteremia in crayfish [2], [3], [4]. Whereas, fungal isolates of crayfish were identified as Aphanomyces sp., Fusarium sp., and Saprolegnia sp. [2], [4], [5].

Research studies on virus pathogens of freshwater crayfish have attracted interests for decades with a growing number of published reports since the last 10 years. Different viruses, including Cherax quadricarinatus presumptive hepatopancreatic reovirus [6], Pacifastacus leniusculus bacilliform virus (PIBV) [7], white spot syndrome virus (WSSV or WSBV) [8], Infectious pancreatic necrosis virus (IPNV) [9], Infectious hypodermal and haemotopoietic necrosis virus (IHHNV) [10], chequa iflavirus [11], and athabvirus [12].

Histopathology is a tool for the early diagnosing the signs of disease infection before continuing to the next strategy to control the diseases using molecular tools to understand the level of species and strains of the causative agents. To see tissue under a microscope, the sections are stained with one or more pigments. The aim of staining is to reveal cellular components, counter-stains are used to provide contrast. The most commonly used in histopathology is a combination of hematoxylin and eosin (often abbreviated H\&E).

This paper aims to present the signs of mix infections from bacteria, fungi and viruses within the tissues of redclaw crayfish $(C$. quadricarinatus) through histopathology examination using some stains including $H \& E$, Gram-Twort, Periodic Acid-Schiff (PAS), and Phosphotungstic Acid-Eosin (PAE) stains.

\section{MATERIAL AND METHOD}

\section{Source of experimental animals}

About 30 adult redclaw crayfish (BW $27.51 \pm 14.13 \mathrm{~g}$ and $\mathrm{TL} 10.33 \pm 1.83 \mathrm{~cm}$ ) were obtained from the breeding facility at JCU Townsville and transferred into twelve aquaria for the 3 wk study. Each crayfish was randomly distributed within the two systems. Small baskets were placed inside the aquarium (each of $28 \mathrm{~cm}$ wide, $51 \mathrm{~cm}$ in length, and $26 \mathrm{~cm}$ height) and used to house the crayfish with the initial stocking densities of 2 or 3 animals per aquarium. Crayfish were given mixed food, including vegetables (chopped potatoes, carrots, broccoli and lettuce), chicken and prawn pellets as required. Daily water exchanges were performed to maintain appropriate water quality. Water $\mathrm{pH}$ was checked using test strips (Quikchek5, Australia) whereas water temperature was measured using a thermometer. The experimental aquaria were monitored daily and any dead crayfish were removed and recorded. Moribund were counted as dead crayfish and they were immediately prepared for processing for histological analyses.

\section{Histopathology}

Prior to histological examination, crayfish were preserved by injecting the cephalothorax and abdominal muscles with Davidson's fixative $(5-10 \mathrm{ml})$ until an orange colour was visible along the bodies. Each crayfish was placed individually into Davidson's fixative with the composition of $1: 10$, so $1 \mathrm{~g}$ crayfish required $10 \mathrm{ml}$ solution.

Prior to histological preparation, the redclaws were anaesthetized in chilled water for about $5 \mathrm{~min}$. At the next stage, each prechilled crayfish was prepared for histology by longitudinally slicing the cephalothorax, abdomen, and gill tissues at approximately 2$3 \mathrm{~mm}$ thickness to obtain separate histological sections of the tissues. The samples were transferred into histocassettes and were fixed in Davidson's solution for $48 \mathrm{hrs}$. Finally, before the samples were embedded in paraffin wax, the tissues were transferred into $70 \%$ ethanol and processed routinely for histology using Shandon Elliot processor to dehydrate in graded ethanol $70 \%, 80 \%, 90 \%, 95 \%$ and $100 \%$ and then 
cleared with xylene, prior to the paraffifin embedded procedure.

Sections were cut at $5 \mu \mathrm{m}$ and each section stained for routine histology process. Initially, sections were grouped, and each group was stained with Mayer's hematoxylin and eosin (H\&E) according to the protocol [[13] in [3]]. H\&E stain is the most widely used histologic stain. Hematoxylin stains nuclei blue or black, while eosin stains cytoplasm and the extra-cellular connective tissue matrix pink,orange and red.

Following H\&E, other groups of tissue sections were stained with special stains, including Gram-Twort, PAS, and PAE following the manufacturer's protocol (Sigma-Aldrich, Australia). Gram-Twort was used to distinguishes Gram-positive (red) and Gramnegative (purple) by ionic bonding and differential staining. Whereas Periodic AcidSchiff (PAS) was used to detect the presence of fungi and/or the hyphae. The Schiff reagent gives a purple-magenta colour. A suitable basic stain is often used as a counterstain.

Phosphotungstic Acid-Eosin (PAE) is a mix of eosin with phosphotungstic acid. It stains some tissue in contrasting colors in a way similar to H\&E stain, as phosphotungstic acid binds to tissue proteins. Muscle is stained blueblack to dark brown, connective tissue is pale orange pink to brownish red, fibrin and nueroglia stain deep blue, coarse elastic fibers show as purple, and bone and cartilage obtain yellowish to brownish red color.

After staining, a light microscope (Olympus EC microscope) was used to view the sections. Photographs were taken using QCapture.Pro.

\section{RESULTAND DISCUSSION}

Redclaw crayfish have been shown to be susceptible to different diseases and parasites, although none have been shown to be accountable for significant commercial mass mortality. However, complacency within the industry, and on farms, with respect to controlling the movement of animals, equipment and water, could result in severe disease outbreaks [1].

In this study, we confirm the cause of mortality of our redclaw crayfish through observation of the macro/gross signs and microscopic analyses by histopathology using different stains.

\section{Mortality Rates (\%)}

Mortality or death rate was measured daily as the number of deaths divided by the number of the survivors in percentage $(\%)$. The chart below (Figure 1) showed the increase in the percentage of mortality (\%) of the redclaw over the $3 \mathrm{wk}$ period of this study. The cause of the mortality then was confirmed by histopathology analyses.

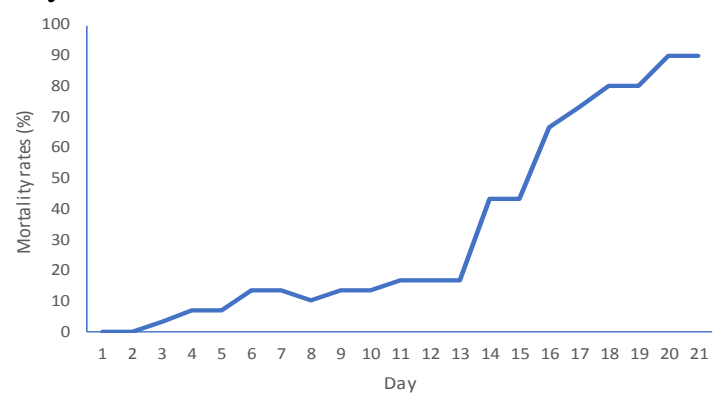

Figure 1. Mortality rates (\%) of the redclaw

\section{Histopathology}

Photographs below are the results of histopathological examination of different tissues of redclaw crayfish (C. quadricarinatus) in this study.

Several symptoms such as lethargy, slow response of flicking tails, and the crayfish becoming slower to reverse their body, also supported the idea of diseases infections. The histopathology of hepatopancreatic tissue (Figure 2A). confirmed virus infection, similarly with the sign of $C$. quadricarinatus hepatopancreatic reo-like virus $(\mathrm{C} q \mathrm{RV})$ infection [3] (Hayakijikosol and Owens; 2011). In addition, the redclaw showed lowered appetite, causing catabolism to process their muscles (see in Figure 4B). Catabolism triggers the breaking down of the actual tissue mass for energy supply when stress or poor diet is affecting the body. Continued catabolism enabled access for bacteria to grow (Figure 4C).

Lots of progress have been made in the last years understanding crayfish immunity [13] since the first identification of products from fungi, $\beta$-1,3-glucans that could activate prophenoloxidase (proPO) and subsequent melanization to the generation of several crayfish transcriptomes and intense studies on how blood cells are produced [16]. 
Like other crustacean immunity, the crayfish immune system consists of proPro as one of their major host defence systems. The activation of proPro enzymes induces the production of phenoloxidase (PO), which is responsible for the melanization. Melanization is an important immune component of the innate immune system of invertebrates and is vital for defense as well as for wound healing [17]. In previous studies, proPO activating system has been identified in freshwater crayfish, Pacifastacus leniusculus [17], [18] and in red swamp crayfish [19].

Nodule formation or cell clumping (see in Figure 4A) indicated the number of invaders outweighed the ability of phagocytosis which is the most common cellular defense reactions once an intruder has overcome the physicochemical barrier of the cuticle [20]. The host's PO activity causes the nodule to become heavily melanised [17].

There are several pathogen associated molecular patterns (PAMPs) such as $\beta-1,3$ glucan from fungus, peptidoglycan by both gram-positive and gram-negative bacteria and LPS from gram-negative bacteria which are recognized by pattern-recognition proteins (PRPs) such as $\beta$-glucan binding protein ( $\beta$ GBP), peptidoglycan binding protein (PGBP), lipopolysaccharide (LPS) and glucan binding protein (LGBP), thioester-containing proteins (TEP), fibrinogen-related proteins (FREP), masquerade-like proteins/serine protease homologues (SPH) and C-type lectins [15], [21], [22].

Upon recognition of PAMPs by PRPs on host cell, the immune system is activated. Phagocytosis, nodule formation, coagulation and encapsulation of the pathogens are the responsibilities of the cellular immunity. Production of antimicrobial peptides and production of toxic phenol intermediates or reactive oxygen species (ROS) and melanin pigments are associated with humoral immunity as schematized in Figure 2A, 3A and 4A-C.

Some photographs presented evidence the defense mechanisms triggered by several cell wall components such as LPS in Gram-negative bacteria and PG of Gram-positive bacteria (Figure 2A \& 2B) or $\beta$-1-3-glucans of fungi (Figure $3 \mathrm{~B}$ ) or endogenous factors causing tissue damage [17]. Water temperature, $\mathrm{pH}, \mathrm{DO}$, salinity, and ammonia (NH3) levels in our aquaria were applicable for rearing the redclaw $\left(27 \pm 1.5^{\circ} \mathrm{C}, 7.0 \pm 0.2,15 \pm 2 \mathrm{ppt}, 2.71-4.32 \mathrm{mg} \mathrm{l}^{-1}\right.$. and $0.03-0.35 \mathrm{mg}^{-1}$, respectively).

\section{CONCLUSION}

Our histopathological study confirmed the signs of co-infection of mix pathogens, including bacteria, fungi and virus triggered the immune response of the redclaw. The opportunity to study the multiple strains of the causative agents and host-pathogens interactions at the molecular level is widely open.

\section{ACKNOWLEDGEMENTS}

This study is supported by the Australian Development Scholarship. 

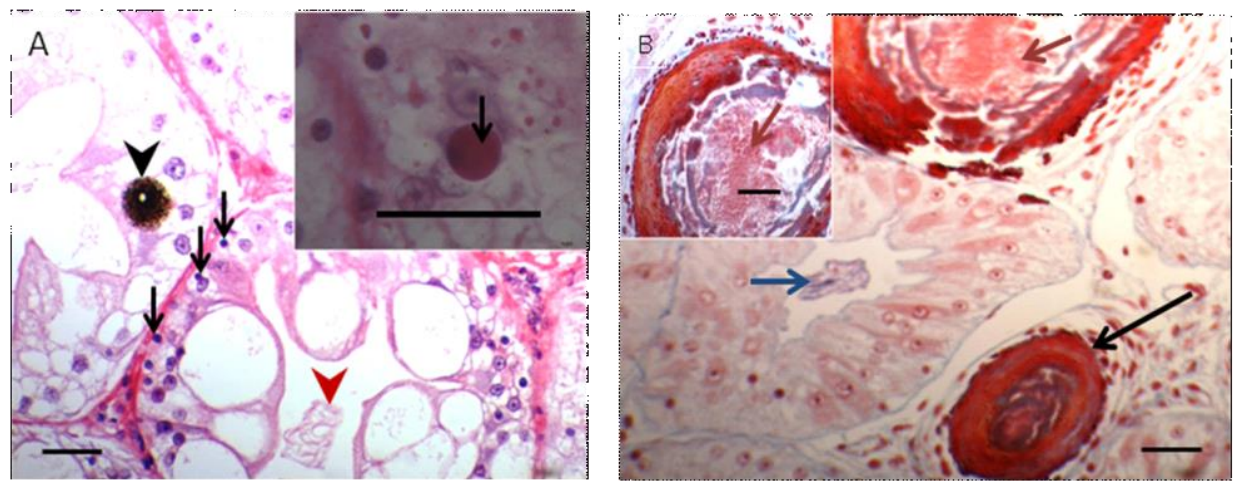

Figure 2. Hepatopancreatic tissues of the redclaw. A. Melanisation (arrowhead), signs of virus infection inside the tubules (arrows), and bacterial colonies inside the lumen (red arrowhead) (20x); Insert: Higher magnification (100x) of the inclusion body (arrow). PAE. B. Gram negative bacterial colonies (red arrows), melanisation surrounded by haemocytic aggregation inside a haemolymph vessel between tubules (black arrow), and Gram-positive bacterial colonies (blue arrow) inside a lumen in the hepatopancreas (20x). Insert: Higher magnification (40x) of the melanisation. Gram Twort. Bars $50 \mu \mathrm{m}$.
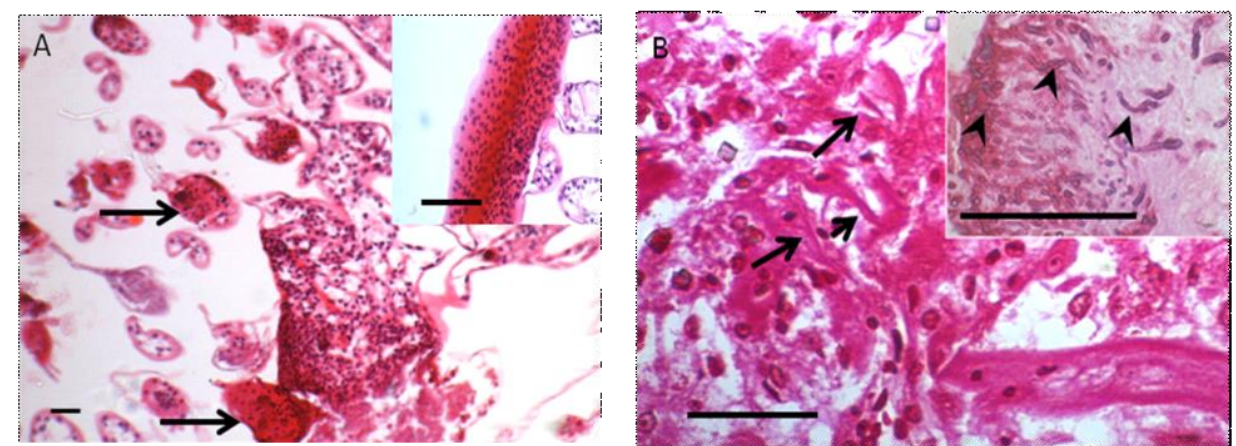

Figure 3. Signs of bacterial and fungal infections in gills of the redclaw. A. Melanization (10x) (arrows). Insert: Higher magnification (20x) of the melanization; B. Presence of fungal hyphae (arrows). Insert: Higher magnification (100x) of fungal hyphae (arrowheads). PAS. Bars 50 $\mu \mathrm{m}$.
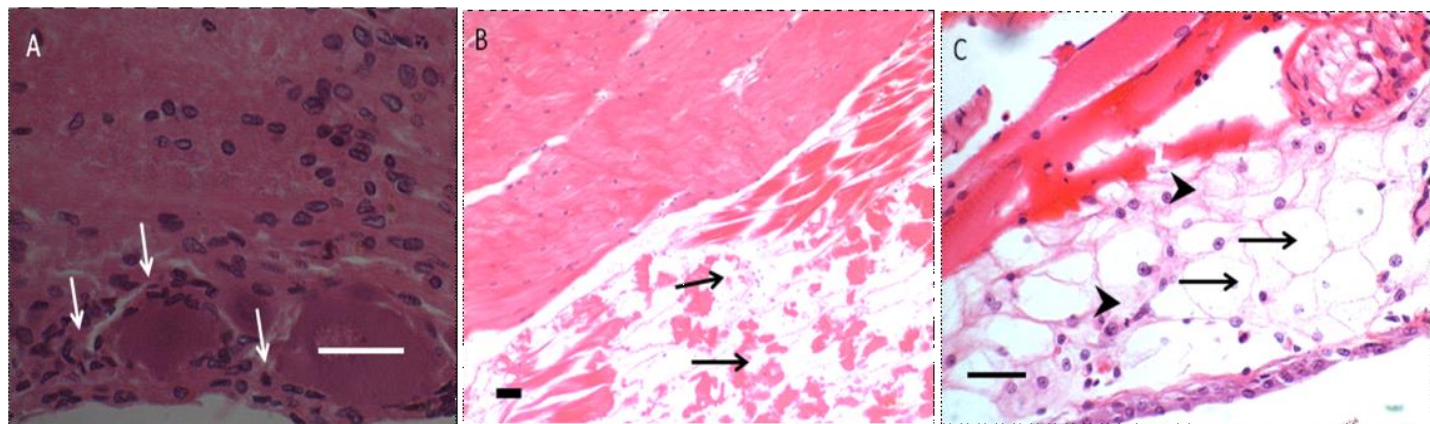

Figure 4. Signs of infection and degradation in muscles of the redclaw. A. Multiple nodule formation surrounded by melanization with continued haemocytic aggregation and whirling (arrows); B. Early stage of catabolism (arrows); C. Bacterial colonies (arrowheads) occurred during final catabolism (arrows). H\&E. Bars 50 $\mu \mathrm{m}$.

\section{REFERENCES}

[1] I. Ruscoe," Redclaw Crayfish Aquaculture (Cherax quadricarinatus)," Fishnote Fisheries, Darwin vol. 32. 6 pp, 2002.

[2] B.F. Edgerton, L.H. Evans, F.J. Stephens and R.M. Overstreet," Synopsis of freshwater crayfish diseases and commensal organisms," Aquaculture, vol. 206, pp. 57-135, 2002.

[3] O. Hayakijikosol, L. Owens and J. Picard," Case report of bacterial infections in a red claw crayfish (Cherax quadricarinatus) 
hatchery," Aquaculture, vol. 475, pp. 1-7, 2017.

[4] R. Salighehzadeh, H. Sharifiyazdi, M. Akhlaghi, M. Khalafian, A. Gholamhosseini, and S. Soltanian, "Molecular and clinical evidence of Aeromonas hydrophila and Fusarium solani co-infection in narrow-clawed crayfish Astacus leptodactylus," Dis. Aquat. Org., vol. 132, pp. 135-141, 2019.

[5] C.Y. Hsieh, C.W. Huang, and Y.C. Pan," Crayfish plague Aphanomyces astaci detected in redclaw crayfish, Cherax quadricarinatus in Taiwan," J. Inv. Pathol., vol. 136, pp. 117-123, 2016.

[6] O. Hayakijikosol and L., Owens," Investigation into the pathogenicity of reovirus to juvenile Cherax quadricarinatus," Aquaculture, vol 316, pp. 1-4, 2011.

[7] M. Longshaw, K.S. Bateman, P. Stebbing, G.D. Stentiford, and F.A. Hockley," Disease risks associated with the importation and release of non-native crayfish species into mainland Britain," Aquat. Bio., vol. 16, pp. 1-5, 2012.

[8] D. Zuo, D.L. Wu, C.A. Ma, H.X. Li, Y.H. Huang, D.L. Wang and Y.L. Zhao," Effects of white spot syndrome virus infection and role of immune polysaccharides of juvenile Cherax quadricarinatus," Aquaculture, vol. 437, pp. 235-242, 2015.

[9] R.P. Rud Yu, M.I. Maistrenko, O.L. Bezusiy and L.P., "Experimental Infection of Freshwater Crayfish (Pontastacus leptodactylus) with Infectious Pancreatic Necrosis Virus," Bull. Prob. Bio. Med., vol. 113, pp. 70-74, 2014.

[10] B.K. Chen, D. Zhen, L.D. Peng, Y.Y. Bin, P.N. Yuan, N.Y. Ying, and Y.D. Chun, "Infectious hypodermal and haematopoietic necrosis virus (IHHNV) infection in freshwater crayfish Procambarus clarkia," Aquaculture vol. 477, pp. 76-79, 2017.

[11] K. Sakuna, J. Elliman, and L. Owens L," Discovery of a novel Picornavirales, Chequa iflavirus, from stressed redclaw crayfish (Cherax quadricarinatus) from farms in northern Queensland, Australia," Virus Res., vol. 238, pp. 148-15, 2017.

[12] K. Sakuna, J. Elliman. A. Tzamouzaki, and L. Owens," A novel virus (order Bunyavirales) from farms in northern Australia," Virus Res., vol. 250, pp. 7-12, 2018.

[13]R.A. Drury and E.A. Wallington," Carleton's Histological Techniques. $5^{\text {th }}$ Ed., Oxford University Press, New York, 195 pp., 1980.

[14] O. Hayakijkosol and L. Owens," Nonpermissive $\mathrm{C} 6 / 36$ cell culture for the Australian isolate of Macrobrachium rosenbergii nodavirus," J. Fish Dis., vol. 36 no. 4, pp. 401-409, 2012.

[15] L. Cerenius and K. Söderhäll, "Crayfish immunity-Recent findings," Dev. Comp. Immun. vol. 80, 9. pp. 4-98, 2018.

[16] I. Söderhäll," Crustacean hematopoiesis," Dev. Comp. Immun., vol. 58, pp. 129-141, 2016.

[17] I. Söderhäll, C. Wu, M. Novotny, B.L. Lee, and K. Söderhäll," A novel Protein Acts as a Negative Regulator of Prophenoloxidase Activation and Melanization in the Freshwater Crayfish Pacifastacus leniusculus," J. Bio. Chem., vol. 284, pp. 6301-6310, 2009.

[18] C. Noonin," Melanization and hemoyte homeostasis in the freshwater crayfish, Pacifastacus leniusculus," Digital comprehensive Summaries of Uppsala Dissertation from the Faculty of Science and Technology. 50pp., 2013.

[19] Z. Qin, S. Babu, H. Lin, Y. Dai, H. Kou, L. Chen, J. Li, L. Zhao, and L. Lin," The immune function of prophenoloxidase from red swamp crayfish (Procambarus clarkii) in response to bacterial infection," Fish Shell. Immun., vol. 92, pp. 83-90, 2019.

[20] F. Li, X. Chang, and F. Yang," Different roles of crayfish hemocytes in the uptake of foreign particles," Fish Shell. Immun., vol. 77, pp. 112-119, 2018. 
[21] L. Cerenius, S. Kawabata, B.L. Lee, M. Nonaka, and K. Söderhäll "Proteolytic cascades and their involvement in invertebrate immunity," Trends Biochem. Sci., vol. 35, no. 10, pp. 575-83, 2010.

[22] J.F. Hillyer," Mosquito immunity," $A d v$. Exp. Med. Bio., vol. 708, pp. 218-238, 2010. 